\title{
BATHYCONCHOECIA INCISA SP. NOV. (MYODOCOPA, HALOCYPRIDIDAE), A NEW SPECIES OF OSTRACOD FROM THE NERITIC ZONE OF THE SOUTH CHINA SEA
}

\author{
BY
}

\author{
JIAN-QIANG YIN ${ }^{1}$ ), KAI-ZHI LI and YE-HUI TAN
}

Key Laboratory of Tropical Marine Bioresources and Ecology, South China Sea Institute of Oceanology, Chinese Academy of Sciences, Guangzhou 510301, P. R. China

\begin{abstract}
Specimens previously identified as Bathyconchoecia paulula sensu Yin \& Chen, 1991 and Bathyconchoecia galerita sensu Yin \& Chen, 1991, together with two similar specimens, are reclassified as a new species, Bathyconchoecia incisa sp. nov., which we describe and illustrate in detail here. The present species is similar to Bathyconchoecia sagittarius and Bathyconchoecia kornickeri in having a shallow notch on the posterodorsal corner of the carapace, but can be easily distinguished from these species by the structure of the posterior margin of the carapace and the striated sculpturing on the surface of the valves. The specimens on which this new classification was based were collected at shallow depths $(<125 \mathrm{~m})$ off the east coast of Hainan Island, in the northern South China Sea and in the Zengmu (James) Shoal and adjacent areas in the southern South China Sea. $B$. incisa is likely to be a shallow-water species or has a wide bathymetric range.
\end{abstract}

Key words. - Bathyconchoeciinae, Pacific Ocean, shallow water, systematics, zooplankton

\section{RÉSUMÉ}

Des spécimens précédemment identifiés comme Bathyconchoecia paulula sensu Yin \& Chen, 1991 et Bathyconchoecia galerita sensu Yin \& Chen, 1991, ainsi que deux spécimens similaires, sont reclassés comme espèce nouvelle, Bathyconchoecia incisa sp. nov., que nous décrivons et illustrons en détail ici. La présente espèce est similaire à Bathyconchoecia sagittarius et Bathyconchoecia kornickeri en ayant une petite échancrure à l'angle postéro-dorsal de la carapace, mais peut être facilement distinguée de ces espèces par la structure du bord postérieur de la carapace et la sculpture striée de la surface des valves. Les spécimens à partir desquels est basée cette nouvelle classification ont été collectés à faible profondeur $(<125 \mathrm{~m})$ au large de la côte Est de l'île de Hainan, au nord de la mer de Chine du Sud et dans le Zengmu (James) Shoal et les zones adjacentes en mer de Chine méridionale. Ainsi, $B$. incisa est probablement une espèce d'eau peu profonde ou alors présente un large intervalle bathymétrique.

\footnotetext{
1) Corresponding author; e-mail: jqyin@ scsio.ac.cn

(c) Jian-Qiang Yin 2017.
} 
Mots clés. - Bathyconchoeciinae, Océan Pacifique, eau peu profonde, systématique, zooplancton

\section{INTRODUCTION}

Since the ostracod genus Bathyconchoecia was established by Deevey in 1968 (Deevey, 1968), 21 species (excluding Scottoecia species, which were separated from the genus Bathyconchoecia by Angel in 2012) have been described. However, most Bathyconchoecia species have been recorded from the Atlantic Ocean, with only Bathyconchoecia baskiae Poulsen, 1969, Bathyconchoecia deeveyae Kornicker, 1970, and Bathyconchoecia pacifica Chavtur, 2001 being described from the Pacific Ocean, and only Bathyconchoecia liui from the South China Sea $\left(6^{\circ} 04.55^{\prime} \mathrm{N} 113^{\circ} 35.83^{\prime} \mathrm{E}\right)$ (Poulsen, 1969; Kornicker, 1969, 1991; Chavtur, 2014; Yin et al., 2014). Although Yin \& Chen (1991) described three species of Bathyconchoecia from the South China Sea, Angel (2012; personal communication) suggested that the specimen identified as Bathyconchoecia paulula is in fact a new species. Therefore, we re-examined these type specimens and suggest that the specimens previously identified as B. paulula sensu Yin \& Chen, 1991 and Bathyconchoecia galerita sensu Yin \& Chen, 1991 belong to the same species. Two similar specimens have since been found, one collected from the Zengmu (James) Shoal and adjacent areas in the southern South China Sea, and the other off the east coast of Hainan Island in the northern South China Sea. Here, we describe and reclassify these specimens as a new species of Bathyconchoecia. In addition, 80 species of halocyprid ostracods (excluding Bathyconchoeciinae) had been recorded from the South China Sea, belonging to 29 genera: Alacia (four species), Austrinoecia (one species), Clausoecia (one species), Conchoecetta (two species), Conchoecia (five species), Concoecilla (one species), Concoecissa (four species), Disconchoecia (three species), Gaussicia (three species), Juryoecia (one species), Kyrtoecia (one species), Loricoecia (two species), Macroconchoecia (two species), Metaconchoecia (one species), Mikroconchoecia (two species), Mollicia (two species), Muelleroecia (two species), Orthoconchoecia (five species), Paraconchoecia (12 species), Paramollicia (three species), Porroecia (five species), Proceroecia (five species), Pseudoconchoecia (one species), Halocypria (one species), Halocypris (one species), Fellia (three species), Archiconchoecia (one species), Archiconchoecissa (one species) and Euconchoecia (five species) (Yin \& Chen, 1991; Chen \& Lin, 1995). 


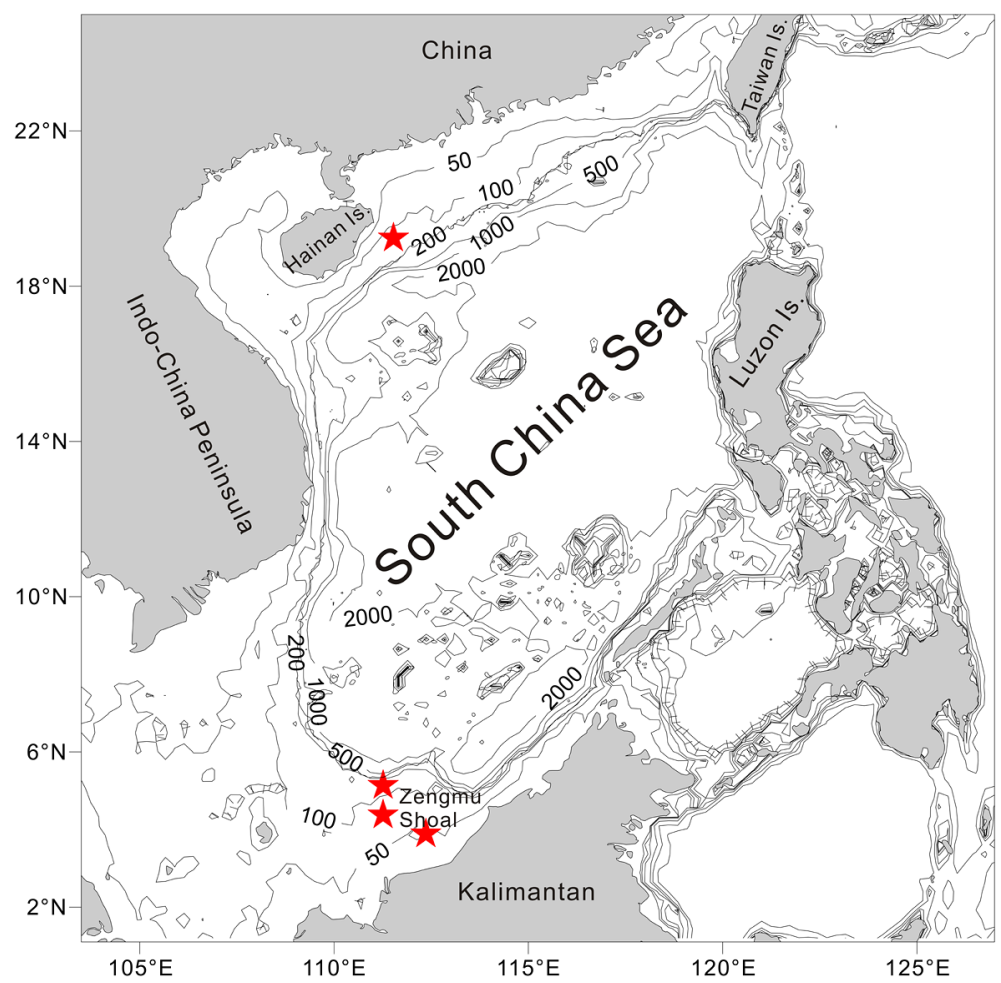

Fig. 1. The sites where specimens of Bathyconchoecia incisa sp. nov. were collected (red stars). This figure is published in colour in the online edition of this journal, which can be accessed via http:// booksandjournals.brillonline.com/content/journals/15685403.

\section{MATERIAL AND METHODS}

During the 1980s and 2000s researchers from the South China Sea Institute of Oceanology, Chinese Academy of Sciences, using 0.505 or $0.169-\mathrm{mm}$ mesh plankton nets, collected large numbers of samples of zooplankton from the southern South China Sea and the northwest continental shelf of the South China Sea, respectively (Yin \& Chen, 1991; Xiong et al., 2012). Among the samples, four specimens of Bathyconchoecia incisa sp. nov. were recorded, and the sites where they were found are shown in fig. 1.

The carapace length (CL), height and width of each specimen were measured using a stereomicroscope at $36 \times$ magnification with a calibrated eyepiece micrometer. The specimen was dissected, and the limbs were placed on a series of slides under a stereomicroscope. The limbs and setae were measured using a microscope and an eyepiece micrometer. These measurements were standardized by expressing them as percentages of the carapace length (\% CL). The complete animal and its limbs were drawn using camera lucidas. The illustrations for publication were inked from these penciled drawings. One of the paratype specimens 
(SCSMBC008023) was photographed using a Leica MC120 HD microscope camera.

\author{
DESCRIPTION — SYSTEMATICS \\ Class OSTRACODA Latreille, 1802 \\ Subclass MYODOCOPA Sars, 1866 \\ Order HALOCYPRIDA Dana, 1853 \\ Suborder HALOCYPRIDINA Dana, 1853 \\ Family HALOCYPRIDIDAE Dana, 1853 \\ Subfamily BATHYCONCHOECIINAE Angel \& Graves, 2013 \\ Genus Bathyconchoecia Deevey, 1968 \\ Bathyconchoecia incisa sp. nov.
}

(figs. 2-6)

Bathyconchoecia pauluta Deevey, 1968 - Yin \& Chen, 1991: 79, fig. 17.

Bathyconchoecia galerita Deevey, 1968 - Yin \& Chen, 1991: 79, 80, fig. 18.

Not Bathyconchoecia pauluta Deevey, 1968: 547-551, figs. 1-3. - Poulsen, 1972: 452, fig. 4;

Kornicker, 1991: 28-30, figs. 14-19.

Not Bathyconchoecia galerita Deevey, 1968: 557-561, figs. 8, 9.

Holotype.- Registration number SCSMBC008020, adult female; deposited in the South China Sea Institute of Oceanology, Chinese Academy of Sciences, Guangzhou, P. R. China.

Type locality.- Northwest of Zengmu (James) Shoal, $5^{\circ} 07.90^{\prime} \mathrm{N} 111^{\circ} 15.78^{\prime} \mathrm{E}, 2$ June 1985 , sounding $119 \mathrm{~m}$, vertical haul from 115 to $0 \mathrm{~m}, 0.505-\mathrm{mm}$ mesh net.

Paratypes.- Registration number SCSMBC008021, A-1 male, Northwest of Zengmu Shoal, $4^{\circ} 22.32^{\prime} \mathrm{N} 111^{\circ} 15.67^{\prime} \mathrm{E}, 2$ June 1985 , sounding $83 \mathrm{~m}$, vertical haul from 80 to $0 \mathrm{~m}, 0.505-\mathrm{mm}$ mesh net; Registration number SCSMBC008022, A-1 male (length $1.14 \mathrm{~mm}$, height $0.74 \mathrm{~mm}$, width $0.67 \mathrm{~mm}$ ), Zengmu Shoal, $3^{\circ} 52.95^{\prime} \mathrm{N} 112^{\circ} 21.76^{\prime} \mathrm{E}, 29$ April 1986, sounding $50 \mathrm{~m}$, vertical haul from 49 to $0 \mathrm{~m}, 0.505-\mathrm{mm}$ mesh net; Registration number SCSMBC008023 (fig. 2), A-2 sex unknown (length $1.02 \mathrm{~mm}$ and height $0.78 \mathrm{~mm}$ ), off the east coast of Hainan Island, $19^{\circ} 14.20^{\prime} \mathrm{N} 111^{\circ} 31.75^{\prime} \mathrm{E}$, 19 April 2007, sounding $129 \mathrm{~m}$, vertical haul from 125 to $0 \mathrm{~m}, 0.169-\mathrm{mm}$ mesh net. All the paratypes have been deposited in the South China Sea Institute of Oceanology, Chinese Academy of Sciences, Guangzhou, P. R. China.

Etymology.- The specific name is derived from the Latin 'incisus' (= cut and notched), and refers to the shallow notch on the posterodorsal corner of this species.

\title{
Adult female.
}

Carapace (fig. 3A, B).- The carapace is almost globose. The carapace length (CL) is $1.21 \mathrm{~mm}$, the height is $0.85 \mathrm{~mm}(70.3 \% \mathrm{CL})$, and the width is $0.77 \mathrm{~mm}$ $(63.6 \% \mathrm{CL})$. The anterior half of the carapace is subequal in size to the posterior half. The anteroventral and posteroventral corners are well rounded. There 


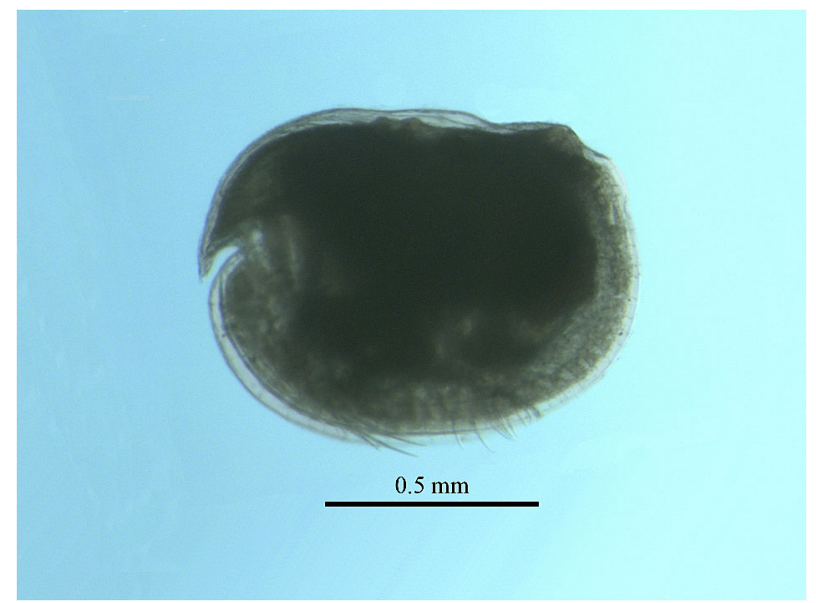

Fig. 2. Photograph of Bathyconchoecia incisa sp. nov., A-2 sex unknown, paratype (SCSMBC008023). This figure is published in colour in the online edition of this journal, which can be accessed via http://booksandjournals.brillonline.com/content/journals/15685403.

is a shallow notch on the posterodorsal corner. The posterior margin is smooth. The ventral margin is smoothly bent. The dorsal margin is nearly straight and there is a clear sulcus in approximately the middle of the hinge line. The asymmetrical glands open symmetrically at the dorsal margin near to the posterodorsal corner. The shoulder vaults are well developed and smoothly rounded. The rostrum bends sharply down and is pointed at the tip. The incisure is narrow and deep (14.0\% CL from the tip of the rostrum to the inner margin). The sculpturing of the carapace is distinct. The entire surface of the carapace is entirely covered with tiny pits, but there are no striations or reticulations.

Frontal organ.- Frontal organ is absent.

First antenna (fig. 3C).- The limb is typical of the genus. It is approximately 24.8\% CL and appears to comprise six segments (Angel \& Graves, 2013). The fifth segment carries distodorsally a plumose seta $(26.4 \% \mathrm{CL})$ and ventrally a cluster of 200-210 sensory filaments (approximately $40.5 \%$ CL), which are arranged in ten rows, each row comprising 20-21 filaments. The plumose seta is approximately two-thirds of the length of the sensory filaments. The terminal segment carries four setae distally. The principal seta is obviously longer than the sensory filaments, and the remaining three setae are almost subequal and shorter than the sensory filaments. The main seta is $53.7 \% \mathrm{CL}$ and the other three setae are 33.1, 33.9 and $31.4 \%$ CL, respectively.

Second antenna (fig. 3D, E).- The limb is typical of the genus. The protopodite is ham-shaped $(40.5 \% \mathrm{CL})$, and its length is obviously longer than its width. The exopodite comprises nine segments. The first exopodite segment $(23.1 \% \mathrm{CL})$ is 


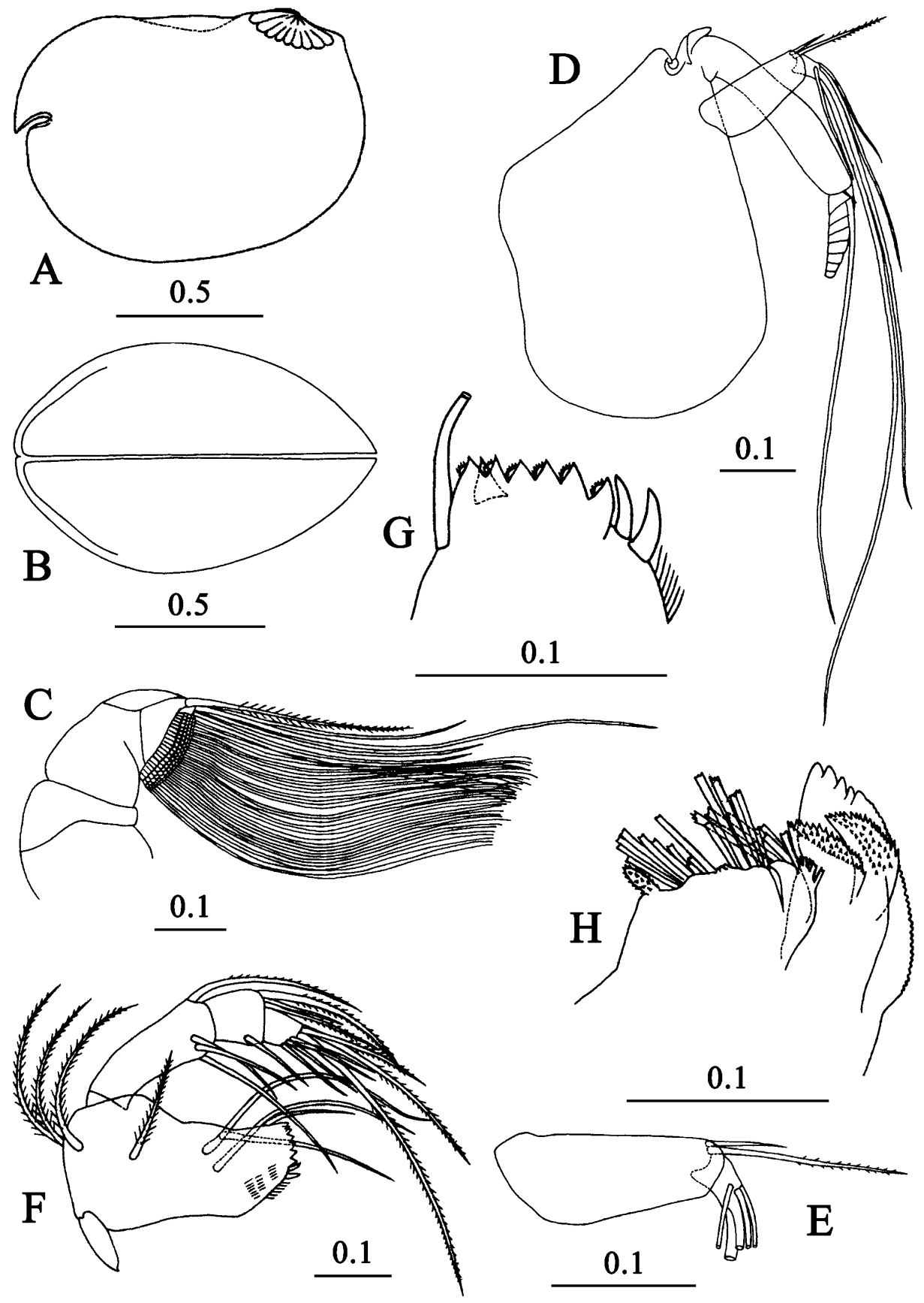

Fig. 3. Bathyconchoecia incisa sp. nov., adult female, holotype: A, carapace, lateral view; B, carapace, ventral view $C$, first antenna; $D$, second antenna; $E$, endopodite of second antenna; F, basis and endopodite of mandible; $\mathrm{G}$, toothed edge of basis of mandible; $\mathrm{H}$, coxal endite of mandible. Scale bars $=\mathrm{mm}$. 
slightly bent and carries a small terminal seta that reaches the third segment. Segments 2-9 each carry a long swimming seta and have a combined length of 9.9\% CL. The endopodite comprises two segments. The first endopodite segment $(13.2 \% \mathrm{CL})$ is elongate and almost rectangular, and one third of the length of the protopodite. It carries two distodorsal setae. The a-seta ( $4.8 \% \mathrm{CL})$ is bare and less than half of the length of the b-seta $(11.7 \% \mathrm{CL})$. The b-seta has distally marginal spinules and is shorter than the first endopodite segment. The second endopodite segment carries five setae. The f-, g-, h-, i- and j-setae are 71.9, 49.6, 13.2, 24.8 and $13.2 \% \mathrm{CL}$, respectively. They are all longer than the b-seta of the first endopodite segment, the longest of which is longer than the swimming setae. The swimming seta of the second exopodite segment is $47.1 \% \mathrm{CL}$.

Mandible (fig. 3F-H). - The toothed edge of the coxal endite has five cutting teeth, which diminish in size along the distal edge; the anterior edge is serrated. The proximal and distal tooth lists have a quantity of denticles, which are irregular in size and arrangement. The masticatory pad has numerous robust, long columnar spines with spinous tips, and a large finger-like spinose process. The toothed edge of the basal endite has six triangular cutting teeth with secondary serrations, and two pointed spine teeth. The basal endite has four plumose setae near the insertion of the endopodite and four bare setae on the anterior edge and lateral surface of the endite. The first endopodite segment has one distodorsal seta and three ventral setae. The second endopodite segment has three distodorsal setae and one ventral seta. The end segment has seven terminal setae, one of which is extremely long (35.5\% CL) and exceeds the length of the endopodite.

Maxilla (fig. 4A, B).- The precoxal endite has six setae, two of which are tubelike. The coxal endite is distally divided into two lobes. It has a total of 10 setae, three of which are tube-like. The basis has one plumose and one bare setae. The endopodite comprises two segments. The anterior margin of the first endopodite segment has a group of three bare setae proximally and one setae distally; the posterior margin has a stout claw-like seta and three plumose setae medially. The terminal segment has two stout terminal claws with spines on the posterior edges, and a pair of slender setae on either side.

Fifth limb (fig. 4C).- The epipodial setae are in three groups of five, four, and four, respectively (not shown). The precoxa has three bare ventral setae. The coxa has eight setae (two plumose and six bare) and two claws on the ventral face. The basis has four bare ventral setae, a pair of plumose lateral setae, and one long distodorsal seta (a remnant of the exopodite, see Angel, 2012) that extends past the end of the limb. The endopodite comprises three segments. The first segment has four bare ventral setae. The second segment has a bare dorsal seta and four bare ventral seta. The third segment has three terminal setae, two of which are clawlike and stout. The dorsal seta $(12.4 \% \mathrm{CL})$ is slightly longer than the central one (10.7\% CL). 

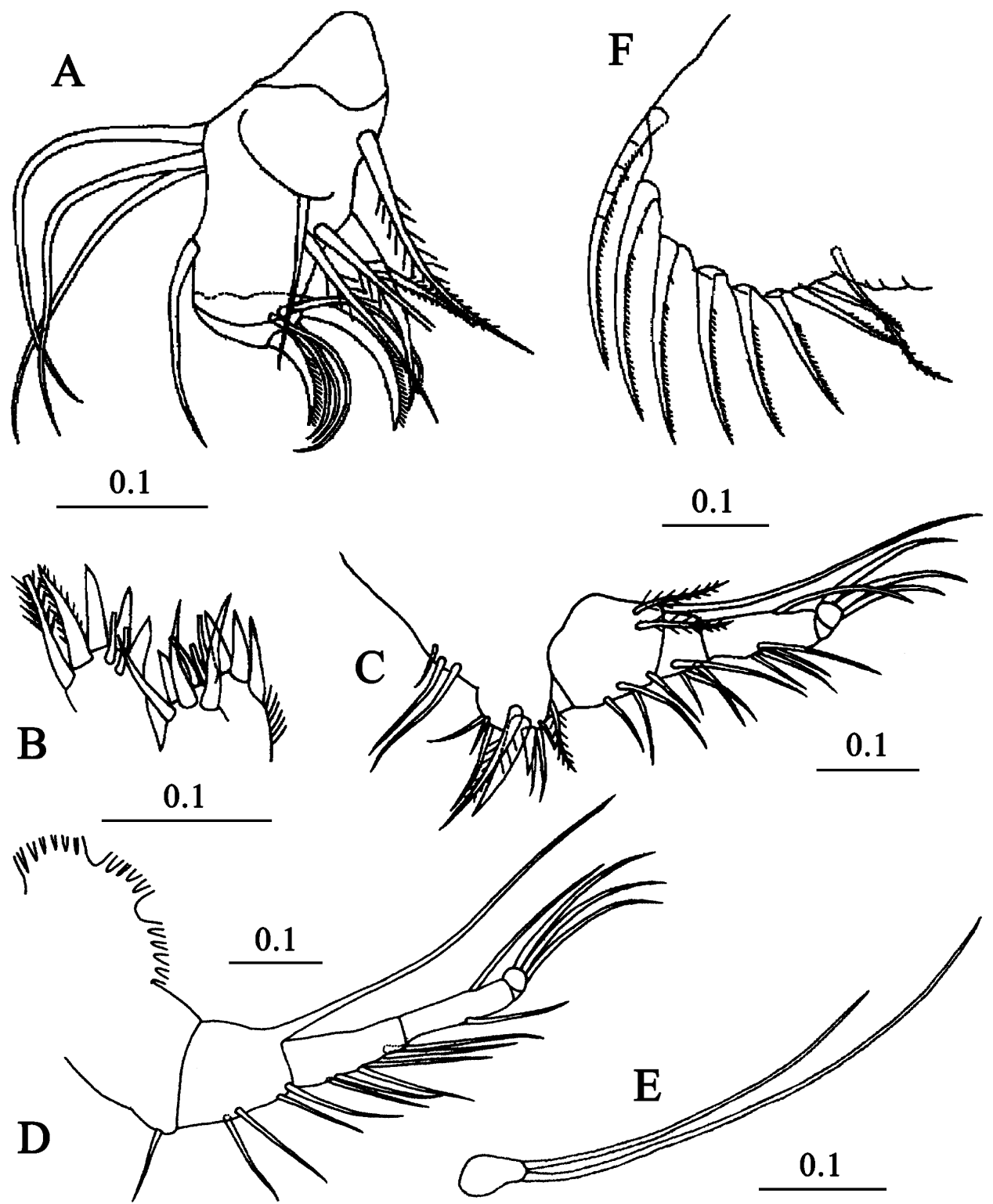

Fig. 4. Bathyconchoecia incisa sp. nov., female, holotype: A, maxilla (without endites, shown in B); $B$, precoxal endite (left) and coxal endite (right) of maxilla; C, fifth limb; D, sixth limb; E, seventh limb; F, caudal furca. Scale bars $=\mathrm{mm}$.

Sixth limb (fig. 4D).- The epipodial setae are arranged in three groups of seven, five and five, respectively. The coxa has a short, bare seta distoventrally. The basis has four bare ventral setae, and an extremely long distodorsal seta (a residual exopodite, see Angel, 2012) that extends beyond the end of the limb. 
The endopodite comprises three segments. The first segment has three pairs of bare ventral setae. The second segment has a ventral and a dorsal setae. The third segment has three terminal setae, of which the dorsal seta (16.5\% CL) is slightly longer than the central setae $(15.7 \% \mathrm{CL})$.

Seventh limb (fig. 4E).- The limb is small and short, and the suture between the two segments is indistinct. The terminal segment bears two unequal and bare setae terminally.

Caudal furca (fig. 4F). - Each lamella has eight long, slim, weak claws, all with two rows of spines on the posterior edge. The first claw is five jointed $(20.7 \% \mathrm{CL})$. There is a long unpaired seta behind the claws.

Immature male (A-1 developmental stage, see Kornicker \& Angel, 1975).

Carapace (fig. 5A-C). - The carapace is little shorter than that of the female, but is slightly relatively longer. The length is $1.20 \mathrm{~mm}$, the height is $0.77 \mathrm{~mm}(64.2 \%$ $\mathrm{CL})$, and the width is $0.74 \mathrm{~mm}(61.7 \% \mathrm{CL})$. The incisure is $13.3 \% \mathrm{CL}$. The ventral margin is almost straight. Otherwise, most of the carapace features are similar to those of the female.

Frontal organ.- There is no frontal organ.

First antenna (fig. 5D).- This limb is similar to that of the female, apart from the fifth segment, which only carries 170-180 ventral sensory filaments (approximately $36.7 \% \mathrm{CL}$ ), which are arranged in ten rows, each comprising 17-18 filaments. The plumose seta on the fifth segment is $20.8 \% \mathrm{CL}$ and the four terminal setae are 47.5, 25.0, 27.5 and $25.0 \% \mathrm{CL}$, respectively.

Second antenna (fig. 5E, F).- The left and right limbs are similar. The protopodite is pear-shaped $(38.3 \% \mathrm{CL})$, and is almost as broad as it is long. The basal half of the first exopodite segment $(19.2 \% \mathrm{CL})$ is bent, but is straight distally. The overall length of the remaining eight exopodite segments is $10.0 \% \mathrm{CL}$. The endopodite comprises three segments. The first endopodite segment is almost rectangular and relatively short $(12.5 \% \mathrm{CL})$. The second endopodite segment has two terminal setae that are relatively short (37.5 and 55.8\% CL, respectively). The third endopodite segment is small and knob-like, and bears three terminal setae of various lengths.

Mandible (fig. 5G-I). - This limb appears to be similar to that of the female, except that one of the two spine teeth on the toothed edge of the basal endite is tubular. The longest terminal seta is $26.6 \% \mathrm{CL}$.

Maxilla (fig. 6A, B).- This limb is similar to that of the female, apart from the fact that all the claws and setae on the endopodite are bare.

Fifth limb (fig. 6C).- The epipodial setae are in three groups of four (not shown). The precoxa has three bare ventral setae. The coxa has seven setae (two plumose, five bare) and two claws on the ventral face. The basis has five bare 


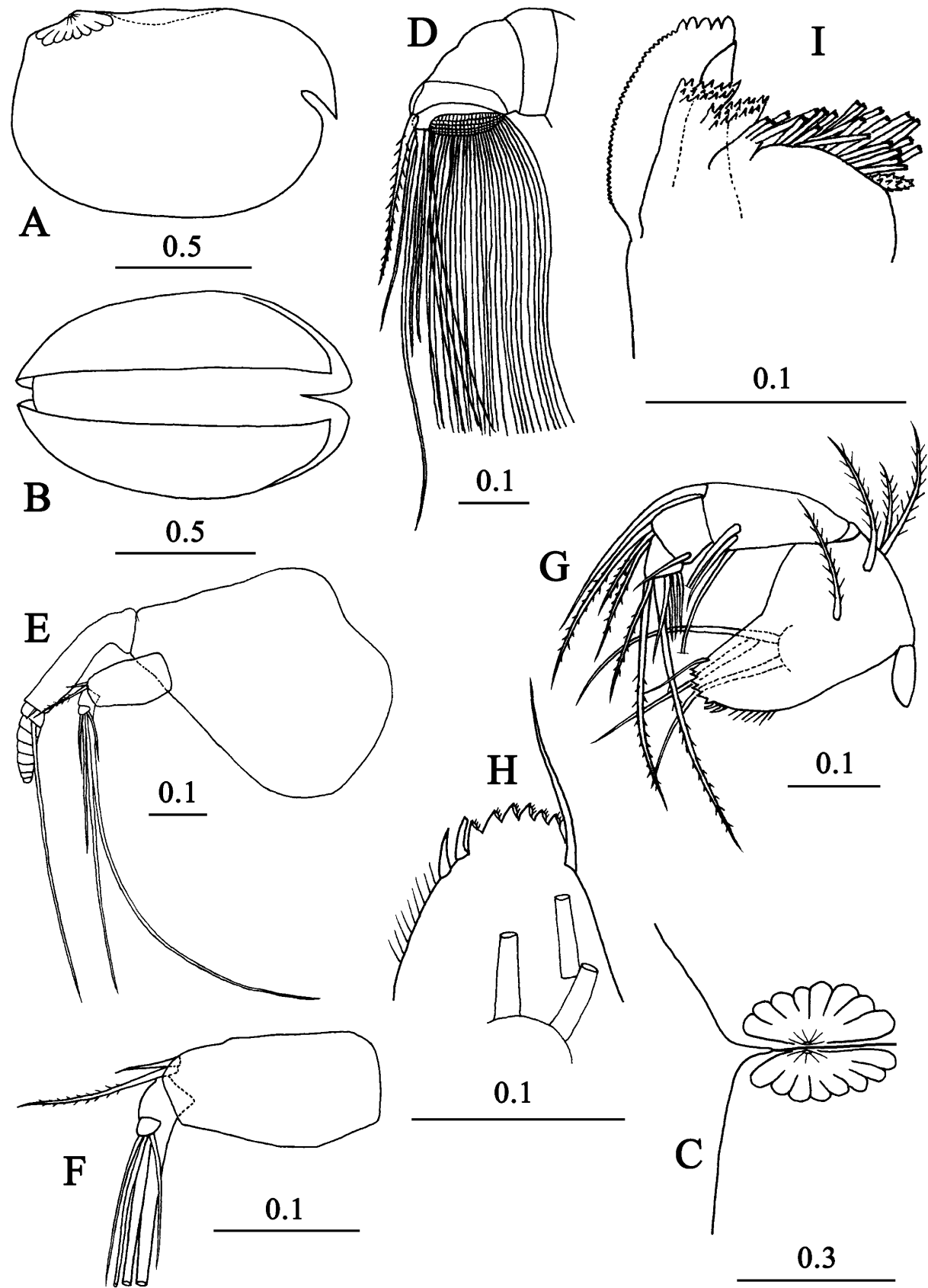

Fig. 5. Bathyconchoecia incisa sp. nov., A-1 male, paratype (SCSMBC008021): A, carapace, lateral view; B, carapace, ventral view; C, posterodorsal corner of carapace opened out and viewed dorsally, showing openings of carapace glands; D, first antenna; E, second antenna; F, endopodite of second antenna; G, basis and endopodite of mandible; H, basal endite of mandible; I, coxal endite of mandible. Scale bars $=\mathrm{mm}$. 

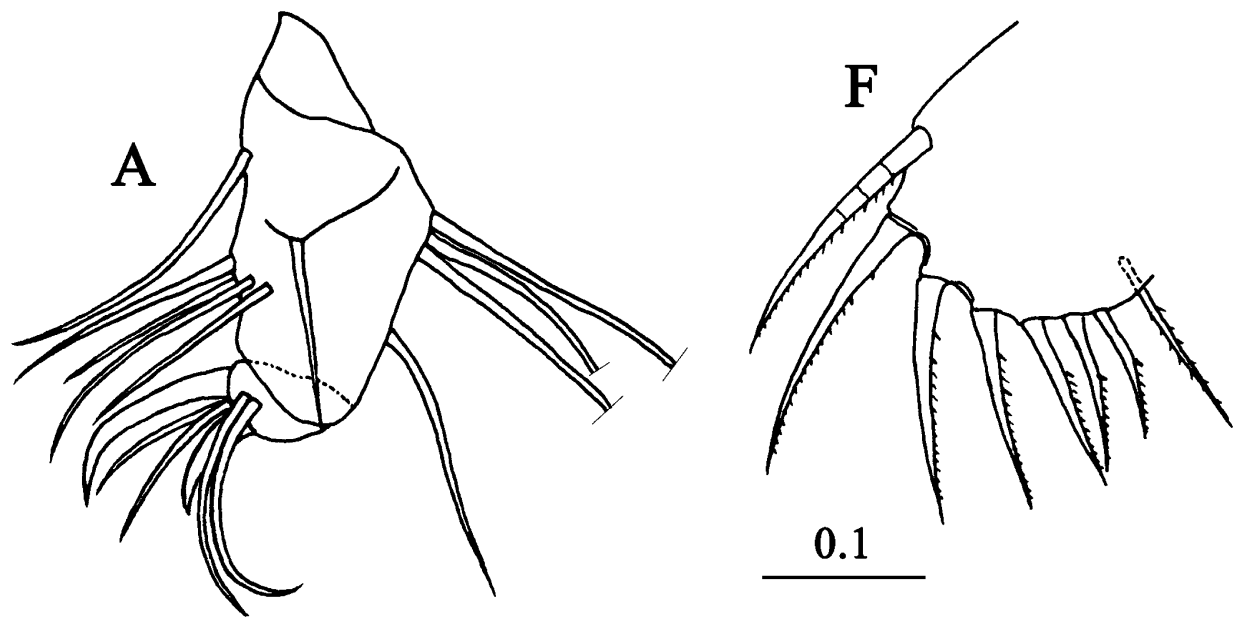

\section{1}
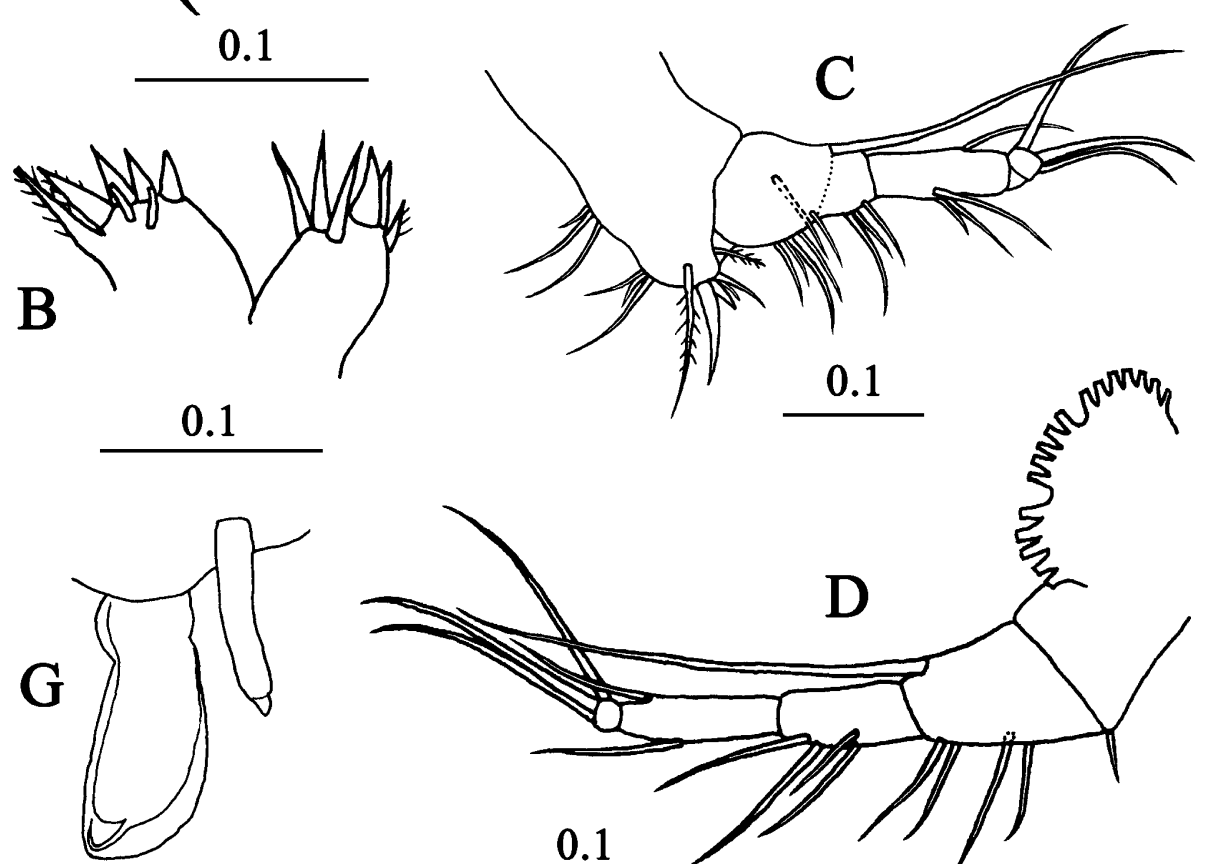

0.1
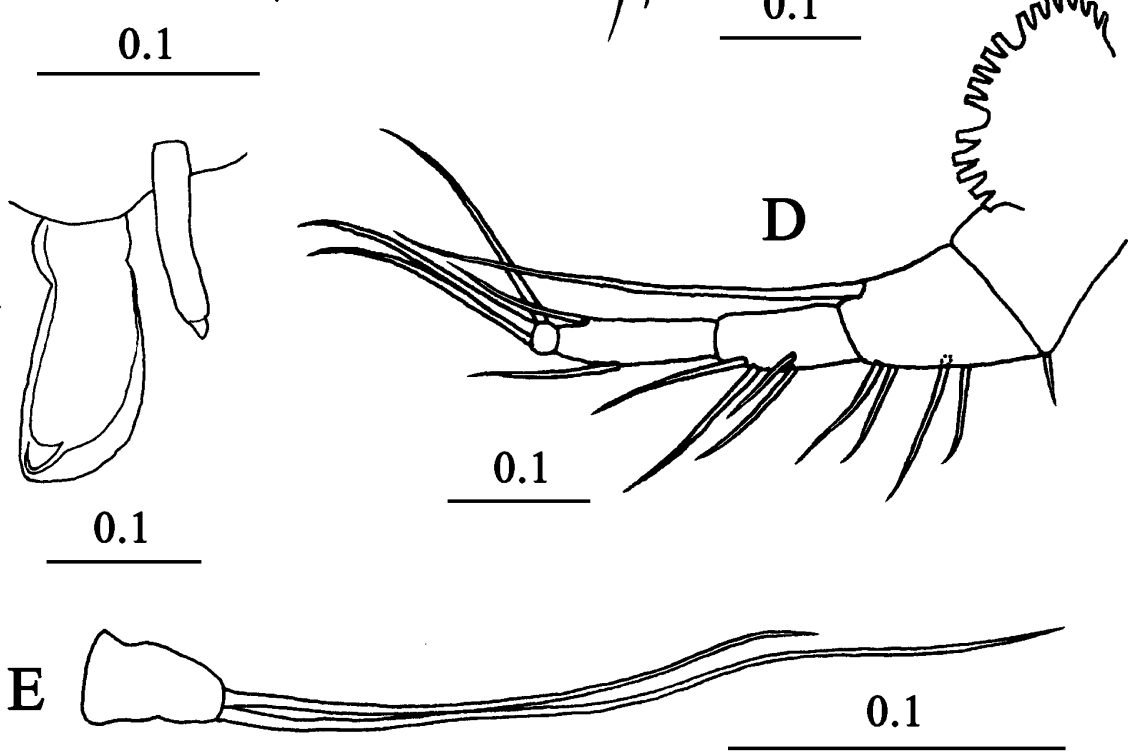

Fig. 6. Bathyconchoecia incisa sp. nov., A-1 male, paratype (SCSMBC008021): A, maxilla (without endites, shown in B); B, precoxal endite (left) and proximal endite of coxal endite (right) of maxilla (distal endite not shown); C, fifth limb; D, sixth limb; E, seventh limb; F, caudal furca; G, copulatory appendage. Scale bars $=\mathrm{mm}$. 
ventral setae, one bare lateral seta, and one long distodorsal seta that extends past the end of the limb. The endopodite comprises three segments, but its segmentation is indistinct (see Angel \& Graves, 2013). The first segment has three bare ventral setae. The second segment has a bare dorsal seta and three bare ventral seta. Unlike in the female, the dorsal and central setae of the third segment are almost equal in length (approximately $10.0 \% \mathrm{CL}$ ).

Sixth limb (fig. 6D).- This limb is similar to that of the female, except that the first endopodite segment has only two pairs of bare ventral setae. The dorsal and central setae of the third endopodite segment are equal in length $(15.0 \% \mathrm{CL})$.

Seventh limb (fig. 6E).- This limb is similar to that of the female.

Caudal furca (fig. 6F). - This has only seven pairs of claws and a long unpaired seta behind the claws. The first claw is four-jointed and it is shorter than that of the female $(15.0 \% \mathrm{CL})$.

Copulatory appendage (fig. 6G).- The appendage is relatively short and bluntly rounded at the tip $(14.2 \% \mathrm{CL})$.

Remarks.- The present species differs from other species of the genus Bathyconchoecia, except from B. sagittarius and B. kornickeri, in that the posterodorsal corner of carapace has a shallow notch (Deevey, 1968; Angel, 1973, 2012). However, it is easily distinguished from these two species by lacking a row of serrations or a flange of sculpturing on the posterior margin of the carapace and by the absence of vertical or irregular striations on the surface of the valves.

\section{DISCUSSION}

Most Bathyconchoecia are deep-water species, with only B. georgei and B. angeli (excluding Scottoecia species) having been collected in the upper $200 \mathrm{~m}$ (George, 1971, 1977; Kornicker \& Rudjakov, 2004). Angel \& Graves (2013) highlighted that all records of Bathyconchoecia species from depths $<500 \mathrm{~m}$ are from upwelling regions. Unusually, all specimens of $B$. incisa sp. nov. were collected at shallow depths $(<125 \mathrm{~m})$ off the east coast of Hainan Island and in the Zengmu (James) Shoal and adjacent areas. The former is a coastal upwelling region (Yin et al., 2011), but the latter is not. Therefore, it is likely that B. incisa is a shallow-water species or that it has a wide bathymetric range.

\section{ACKNOWLEDGEMENTS}

We would like to thank Gu-Xian Zhang for helping to collect samples. We also would like to thank one anonymous reviewer for comments that helped to improve 
the manuscript. This study was supported by the Natural Science Foundation of China (Nos. 41130855 and 41576125).

\section{REFERENCES}

ANGEL, M. V., 1973. The description of the female of the ostracod Bathyconchoecia sagittarius Deevey, 1968 (Myodocopida, Halocyprididae). Crustaceana, 25: 211-219.

ANGel, M. V., 2012. Scottoecia - a new genus of halocyprid ostracod, with the description of Scottoecia arabica nov. sp. and the redescription of Bathyconchoecia darcythompsoni (Scott, 1909). Zootaxa, 3254: 32-54.

Angel, M. V. \& C. Graves, 2013. Bathyconchoeciinae, a new subfamily of deep oceanic planktonic halocyprid Ostracod (Myodocopa, Ostracoda). Zootaxa, 3630: 243-269.

ChaVtur, V. G., 2014. Redescription of Bathyconchoecia pacifica Chavtur, 1977 (Ostracoda, Halocyprididae) from the North Pacific. Publications of the Seto Marine Biological Laboratory, 42: 1-13.

Chen, R. X. \& J. H. Lin, 1995. Pelagic Ostracoda in China Seas: 1-134. (China Ocean Press, Beijing). [In Chinese.]

DeEvey, G. B., 1968. Bathyconchoecia, a new genus of pelagic ostracods (Myodocopa: Halocyprididae) with six new species from the deeper waters of the Gulf of Mexico. Proceedings of the Biological Society of Washington, 81: 539-570.

GeORGE, J., 1971. On the occurrence of Bathyconchoecia deeveyae Kornicker (Ostracoda, Halocypridae) in the Indian Ocean. Crustaceana, 21: 141-144.

GeORGE, J., 1977. Bathyconchoecia angeli sp. nov., a new halocyprid ostracod from the Malacca Strait, Indian Ocean. Crustaceana, 33: 70-74.

KoRNICKER, L. S., 1969. Bathyconchoecia deeveyae, a highly ornamented new species of Ostracoda (Halocyprididae) from the Peru-Chile Trench system. Proceedings of the Biological Society of Washington, 82: 403-408.

Kornicker, L. S., 1991. Myodocopid Ostracoda of hydrothermal vents in the eastern Pacific Ocean. Smithsonian Contributions to Zoology, 516: 1-46.

KORNICKER, L. S. \& M. V. ANGEL, 1975. Morphology and ontogeny of Bathyconchoecia septemspinosa Angel, 1970 (Ostracoda: Halocyprididae). Smithsonian Contributions to Zoology, 195: $1-21$.

Kornicker, L. S. \& J. A. RUdJAKOv, 2004. Two new species of seven-spined Bathyconchoecia from the North Atlantic and Indian Oceans (Crustacea: Ostracoda: Halocypridae). Proceedings of the Biological Society of Washington, 117: 398-407.

Poulsen, E. M., 1969. Ostracoda-Myodocopa. Part IIIA Halocypriformes-Thaumatocypridae and Halocypridae. Dana Report, 75: 1-100.

Poulsen, E. M., 1972. On the Bathyconchoecia (Ostracoda Myodocopa) from the Azores collected by the bathyscaph «Archimede » in 1969. Tethys, 4: 445-455.

Xiong, L. L., J. Q. Yin, L. M. Huang, K. Z. Li \& S. M. Lian, 2012. Seasonal and spatial variations of cladocerans on the northwest continental shelf of the South China Sea. Crustaceana, 85: 473-496.

YIN, J. Q. \& Q. C. CHEN, 1991. Species, fauna and zoogeography of the pelagic ostracods in the waters around the Nansha Islands. In: THE MULTIDISCIPLINARY OCEANOGRAPHIC Expedition Team of Academia Sinica to Nansha Islands (ed.), Marine fauna and zoogeography of the Nansha Islands and neighboring waters: 64-139. (China Ocean Press, Beijing). [In Chinese, with English abstract.]

YIN, J. Q., Q. C. ChEN \& K. Z. LI, 2014. Bathyconchoecia liui n. sp., a new species of ostracod (Myodocopa, Halocyprididae) from the South China Sea. Crustaceana, 87: 1027-1035. 
YIN, J. Q., L. M. HuAng, K. Z. LI, S. M. LiAn, C. L. Li \& Q. LIN, 2011. Abundance distribution and seasonal variations of Calanus sinicus (Copepoda: Calanoida) in the northwest continental shelf of South China Sea. Continental Shelf Research, 31: 1447-1456.

First received 25 May 2016.

Final version accepted 21 October 2016. 